\title{
Contribution to the requalification of Alkali-Silica reaction damaged concrete: particular respect to the slag effect
}

\author{
Zineb DOUAISSIA ${ }^{1}$, Mouloud MERZOUD ${ }^{2}$ \\ ${ }^{1}$ et 2 Badji Mokhtar university, Department of civil Engineering, ANNABA, ALGERIA
}

\begin{abstract}
A significant concern when designing durable concretes structures is the risk of alkali silkai reaction (ASR). The cracks formed by ASR increase the permeability of concrete, reduce the strength and lower the economic lifetime of concrete. The use of mineral and chemical admixtures to prevent expansion due to the alkali-silica reaction (ASR) was first reported 40 to 50 years ago. In this paper, a comprehensive experimental research was carried out to prevent the damages and to be able to improve in concrete structures with the reactive aggregates by using the ground granulated blast-furnace slag (GGBFS) in the mixtures. Furthermore, the engineering properties of blast-furnace slag and the test methodology used in the research were presented and the research findings were also discussed.
\end{abstract}

\section{Introduction}

In the decade following the discovery of the alkali silica reaction (ASR) by Stanton, recommendations, such as the use of non-reactive aggregate or the use of low alkali cement, were made to avoid or to mitigate the disorders due to this reaction.

At the same time, it was established that blended cements made of OPC mixed with pozzolanic admixtures were efficient in reducing ASR expansion. The use of such admixtures (fly ash, silica fume, ground granulated slag) is now current practice to reduce the risk of ASR.

Many references concern the use of ground admixtures added to mixtures containing a reactive aggregate coming from a different source, particularly Hobbs [1], Peter [2], Moir [3], Swamy[4], Hiroshi Nomachi and al [5] and Yoshihiko Ohama and al [6].

The specification of concrete using ground granulated blast-furnace slag (GGBS) is recognised in several countries [7-9] as an possible measure to reduce the risk of deleterious alkali silica reaction occurring in concrete containing potentially reactive aggregates.

However, the effectiveness of GGBS, particularly at levels of cement replacement below 50\%, has been questioned by several workers [10-12].

The aim of this paper is to verify whether ground granulated blast-furnace slag (GGBS) is an efficient and general solution to counteract ASR expansion. Tests were performed on concrete using two reactive aggregates.

\section{Materials}

\subsection{Cement}

The binder was an ordinary Portland cement, CEM I 52,5R as specified by European Standard EN 197-1, with a specific weight of 3,15 , a fineness of $350 \mathrm{~m}^{2} / \mathrm{kg}$ (Blaine) and a moderately high $\mathrm{Na}_{2} \mathrm{O}_{\text {eq }}$ content $(0,8 \%)$. Its chemical composition is presented in Table 1

\subsection{Aggregates}

Two aggregates were chosen :

- A siliceous limestone (H), mainly composed of calcite with a few percent of dolomite. When observed at microscopic level, diagenetic silica is seen to consist mainly of quartz and traces of feldspars, muscovite and kaolinite. This aggregate is also a reactive rock, with a slow rate of silica dissolution.

- A crushed waste glass (G), resulting from the crushing of window glasses. It was chosen because the reuse of waste glasses has been envisaged by several workers in the last decade [13-17]. It had an amorphous structure as determined by X-ray diffraction.

\subsection{Ground Slag}

Ground slag (S) is a byproduct of the development of the cast iron in steel complex of El Hadjar (Annaba), it has a glass structure, a vitrification rate of $97 \%$ and a low hydraulicity.

it's obtained by crushing and sieving at $80 \mu \mathrm{m}$. In order to study the influence of fineness in counteracting expansion, the slag material is ground to different 
specific surface (Blaine), which are $\mathrm{S}_{1}: 100 \mathrm{~m}^{2} / \mathrm{kg}, \mathrm{S}_{2}$ : $400 \mathrm{~m}^{2} / \mathrm{kg}$ and $\mathrm{S}_{3}: 600 \mathrm{~m}^{2} / \mathrm{kg}$, The chemical compositions of this powder appear in Table 1 .

Table 1. Chemical composition of cement, aggregates and ground slag $(\%)$.

\begin{tabular}{|c|c|c|c|c|c|c|}
\hline \multirow{2}{*}{} & \multirow{2}{*}{ cement } & \multicolumn{2}{|c|}{ Aggregates } & \multicolumn{3}{|c|}{ ground slag } \\
\cline { 3 - 7 } & & $\mathrm{H}$ & $\mathrm{G}$ & $\mathrm{S}_{1}$ & $\mathrm{~S}_{2}$ & $\mathrm{~S}_{3}$ \\
\hline $\mathrm{SiO}_{2}$ & 20.1 & 20.0 & 72.1 & 33.0 & 35.4 & 36.1 \\
\hline $\mathrm{Al}_{2} \mathrm{O}_{3}$ & 5.6 & 1.3 & 1.0 & 11.8 & 12.7 & 9.9 \\
\hline $\mathrm{Fe}_{2} \mathrm{O}_{3}$ & 2.0 & 0.6 & 0.1 & 1.6 & 0.30 & 0.79 \\
\hline $\mathrm{CaO}$ & 62.5 & 40.6 & 6.3 & 41.3 & 41.3 & 41.0 \\
\hline $\mathrm{MgO}$ & 3.1 & 1.2 & 3.7 & 9.0 & 06.7 & 9.5 \\
\hline $\mathrm{K}_{2} \mathrm{O}$ & 0.9 & 0.4 & 0.1 & 0.51 & 0.60 & 0.35 \\
\hline $\mathrm{Na}_{2} \mathrm{O}$ & 0.2 & 0.4 & 12.7 & 0.32 & 0.24 & 0.18 \\
\hline $\mathrm{SO}_{3}$ & 3.2 & 0.3 & 0.1 & 0.13 & 0.14 & 0.11 \\
\hline $\mathrm{L}^{2} \mathrm{O} . \mathrm{I}$ & 1.7 & 34.7 & 0.4 & 0.8 & 0.6 & 0.6 \\
\hline
\end{tabular}

\section{Experimental methods}

\subsection{Mortar tests}

The mortar test was an accelerated method using an autoclave apparatus (French Standard P18-594 [18]). This test consisted of measuring the length variations of mortar prisms $(4 \times 4 \times 16 \mathrm{~cm})$ doped with alkalis $(4 \%$ of cement mass) after a treatment lasting $5 \mathrm{~h}$ at $127^{\circ} \mathrm{C}$ and $0,15 \mathrm{MPa}$. Mortars had a water/cement ratio of 0,5 and an aggregate/cement ratio of 3,0 . The first series of tests were performed on mortars containing only cement, water and reactive aggregates $(0,16-2,5 \mathrm{~mm})$. For the second series, cement has been substituted with increasing percentage (by volume) of ground slag : 10, 20 and $30 \%$ of different fineness from 200 to $600 \mathrm{~m}^{2} / \mathrm{kg}$ (Blaine), After this tests, we measured the compressive strength (fc) of each mortar .

\subsection{Concrete tests}

The concrete samples were made, stored and tested according to French Standard P18-454 [19]. This test consisted of evaluating the performance of a concrete with respect to ASR by measuring its expansion on $7 \times 7 \times$ $28 \mathrm{~cm}$ prisms stored at $60^{\circ} \mathrm{C}$ and $100 \%$ relative humidity.
After mixing, the samples were stored in a moist room at $20^{\circ} \mathrm{C}$ for $24 \mathrm{~h}$. Then, the concrete prisms were placed vertically on grids in watertight containers containing 35 $\mathrm{mm}$ of water (the concrete was not in contact with the water).

Each concrete was tested on three prisms and the expansion data represent the average of three measurements. The containers were placed in a reactor generating an atmosphere at $60^{\circ} \mathrm{C}$ and $100 \%$ R.H. Expansion measurements were taken after the containers and their prisms had been cooled for $24 \mathrm{~h}$ at $20^{\circ} \mathrm{C}$. Immediately after each measurement, the prisms were put back into their containers, which were kept in the reactor at $60^{\circ} \mathrm{C}$ until the next measurement. The last measurement was taken at 100 weeks. At the same age map cracking was measured in order to quantify the degree of damage due to ASR and compressive strength (fc) was measured on three cubes $(10 \times 10 \times 10) \mathrm{cm}^{3}$.

Details of the concrete mixtures, including the slump (modified Abram's cone of $200 \mathrm{~mm}$ ) and density, are given in Table 2. Each mixture is designated by a capital letter representing the reactive aggregate used, followed by a small letter for mixtures containing ground slag. The water content of the concrete was set between 197 and $212 \mathrm{l} / \mathrm{m}^{3}$. A significant amount of cement was used (between 442 and $477 \mathrm{~kg} / \mathrm{m}^{3}$ ) in order to obtain high alkali content. However, considering the value of $\mathrm{Na}_{2} \mathrm{Oeq}$ in the cement, it was decided to enhance the alkali content to $35 \mathrm{~kg} / \mathrm{m}^{3}$ by adding $\mathrm{NaOH}$ to the mixing water. Ground slag used to replace $20 \%$ of the sand (by weight) had finenesses of 200,400 , and $600 \mathrm{~m}^{2} / \mathrm{kg}$.

\section{Experimental results and Discussion}

\subsection{Mortars}

Results of the autoclave expansion tests performed on the mortars are given in Fig.1, Such as reducing expansion caused by the slag substitution (in\% of measured value on the mortar without slag).

They confirm that the two aggregates used can be classified as reactive, since the measured expansions varied between 0,30 and $0,38 \%$. These expansions were much higher than $0,15 \%$, the value under which the aggregate is considered as non-reactive according to French standard P18- 594 [18]. The use of ground slag decreased the expansion of mortars. However, their activity depended on the fineness and quantity used.

Table 2 Composition, density and slump of concrete mixtures

\begin{tabular}{|c|c|c|c|c|c|c|c|c|c|c|}
\hline & \multicolumn{8}{|c|}{ Composition } & \multirow{3}{*}{$\begin{array}{l}\text { Density } \\
\left(\mathrm{kg} / \mathrm{m}^{3}\right)\end{array}$} & \multirow{3}{*}{$\begin{array}{l}\text { Slump } \\
(\mathrm{cm})\end{array}$} \\
\hline & \multirow{2}{*}{$\begin{array}{l}\text { Cement } \\
\left(\mathrm{kg} / \mathrm{m}^{3}\right)\end{array}$} & \multirow{2}{*}{$\begin{array}{c}\text { Water } \\
(l)\end{array}$} & \multirow[t]{2}{*}{$\mathrm{W} / \mathrm{C}$} & \multirow{2}{*}{$\begin{array}{c}\text { Superplasticizer } \\
(l)\end{array}$} & \multirow{2}{*}{$\begin{array}{c}\text { Ground Slag } \\
\left(\mathrm{kg} / \mathrm{m}^{3}\right)\end{array}$} & \multirow{2}{*}{$\begin{array}{c}\text { Sand } 0,08-4 \\
\left(\mathrm{~kg} / \mathrm{m}^{3}\right)\end{array}$} & \multicolumn{2}{|c|}{ Aggregate $\left(\mathrm{kg} / \mathrm{m}^{3}\right)$} & & \\
\hline & & & & & & & $4-8$ & $8-16$ & & \\
\hline $\mathrm{H}$ & 477 & 212 & 0.44 & 0 & 0 & 617 & 248 & 929 & 2445 & 4 \\
\hline $\mathrm{H}-\mathrm{S}$ & 467 & 208 & 0.44 & 2.49 & 133.5 & 454 & 242 & 910 & 2397 & 7 \\
\hline G & 452 & 201 & 0.44 & 0 & 0 & 699 & 200 & 766 & 2319 & 4 \\
\hline G-S & 442 & 197 & 0.44 & 4.91 & 136.8 & 546 & 195 & 749 & 2272 & 5 \\
\hline
\end{tabular}



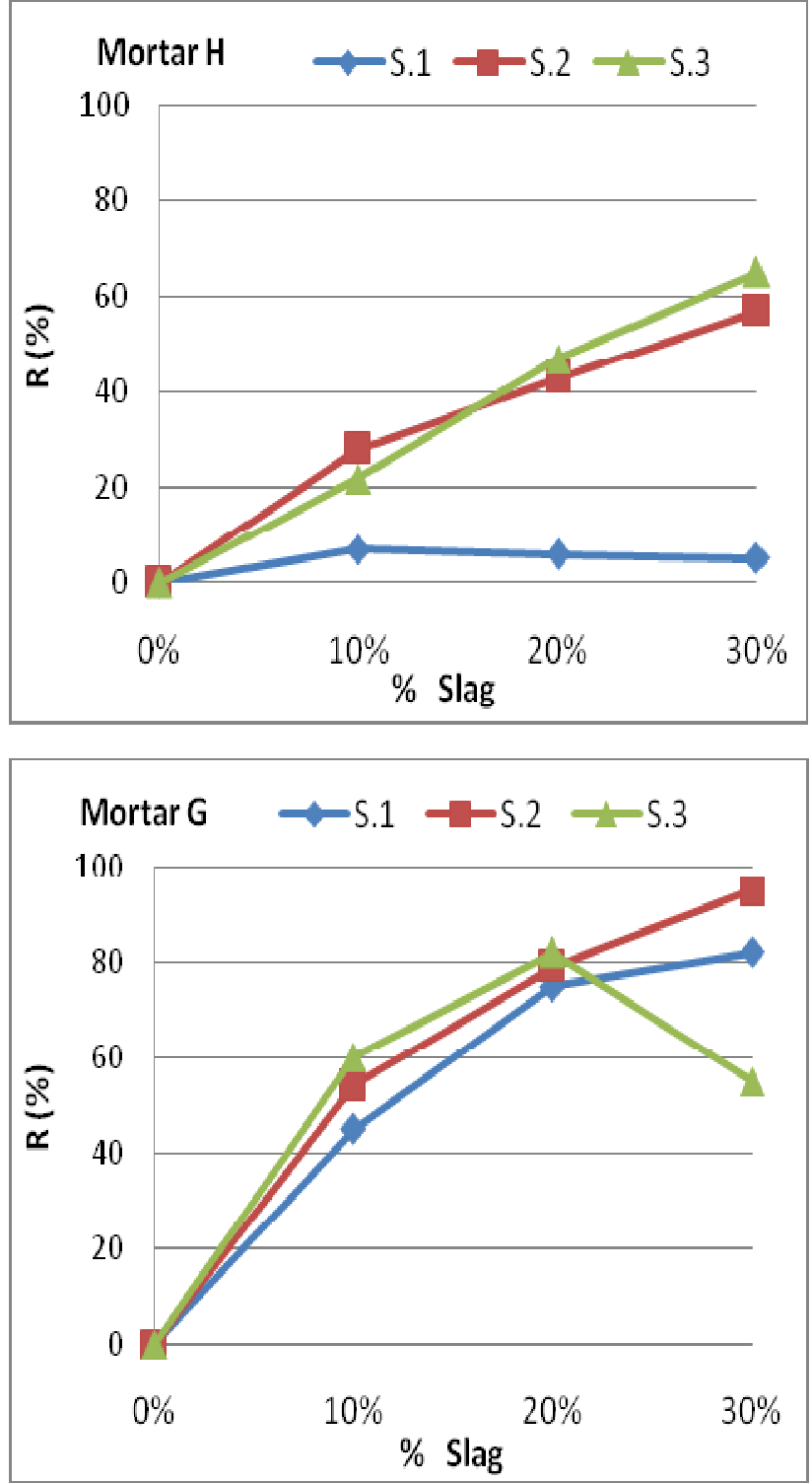

Fig.1. Reduction of expansion (R\%) of mortar versus amount and fineness of slag

After This test, the compressive strength (fc) of each mortar was measured, the main results from compressive tests are reported in Fig.2, it includes the compressive strength for the reference mortars which are undoped mortars (without addition of $\mathrm{NaOH}$ ) , for the mortars at $0 \%$ slag which are doped mortars, for the mortars at different rate of ground slag : 10, 20 and 30\% and different finenesses (Blaine), which are $\mathrm{S}_{1}: 100 \mathrm{~m}^{2} / \mathrm{kg}$, $\mathrm{S}_{2}: 400 \mathrm{~m}^{2} / \mathrm{kg}$ and $\mathrm{S}_{3}: 600 \mathrm{~m}^{2} / \mathrm{kg}$.
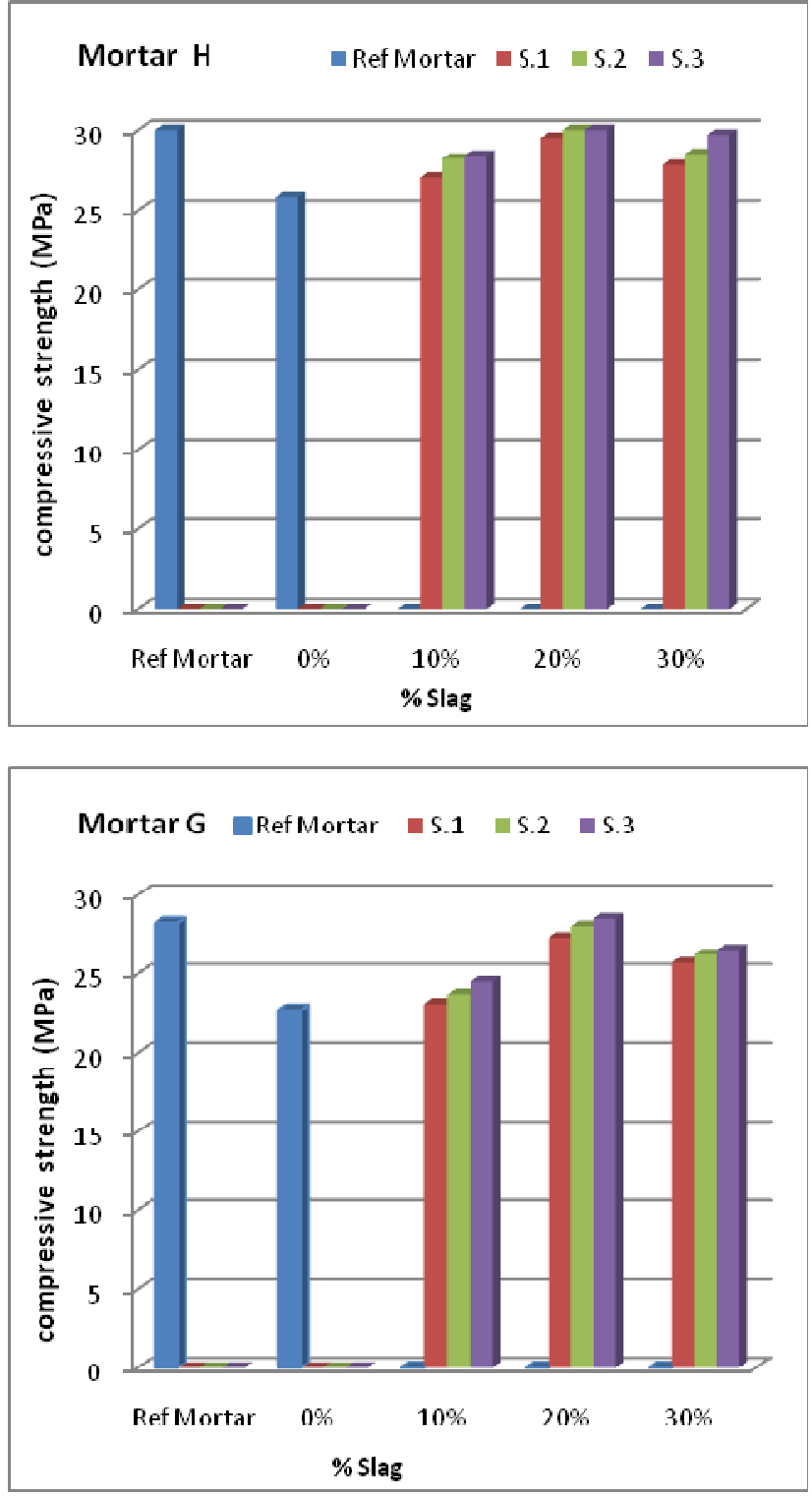

Fig. 2 slag effect on the compressive strength of mortars aged 17 weeks conserved at $60^{\circ} \mathrm{C}$ and $100 \% \mathrm{RH}$.

If we are interested in results for the reference mortars which are undoped mortars (without addition of $\mathrm{NaOH}$ ) and mortars at $0 \%$ slag which are doped mortars, we note that:

- The addition of alkali, which causes expansion, occasions a reduction in strength.

- The increasing substitution rate leads to an increase in strength.

- Differences in strength resulting from two antagonistic actions: the alkali-silica reaction that tends to lower the strength, and slag, which probably by a reaction similar to a pozzolanic reaction, increase this strength. - The slag beneficial effect is measurable by comparing the mortars strength gains with different rate of slag $10 \%, 20 \%$ and $30 \%$, which is $7 \mathrm{MPa}, 20 \mathrm{MPa}$ and 16 $\mathrm{MPa}$ respectively, mortar strength to $30 \%$ of slag is higher than that obtained by the reference mortar did not damaged by alkali-silica reaction. 


\subsection{Concretes}

The length variations of the concrete prisms cured for 100 weeks at $60^{\circ} \mathrm{C}$ and $100 \%$ R.H. are shown in Fig.3. In a first analysis, it can be seen that the concrete $G$ presents an important expansion during the first week, and that the expansion rate decreases after 30 weeks. It is noteworthy that the ground slag reduced the expansion of all concretes, different behaviors show concrete with ground slag, concrete G-S shows a slow expansion rate.

When the expansion of the prisms had practically stabilized, all faces of the $7 \times 7 \times 28 \mathrm{~cm}$ samples were photographed, Crack patterns are shown on Fig 4, The results give information on both the intensity of the damage and the possible isotropic distribution of cracking. We can observed that :

The presence of ground slag dramatically decreased the ASR crack development, as was confirmed by the swelling measurements.

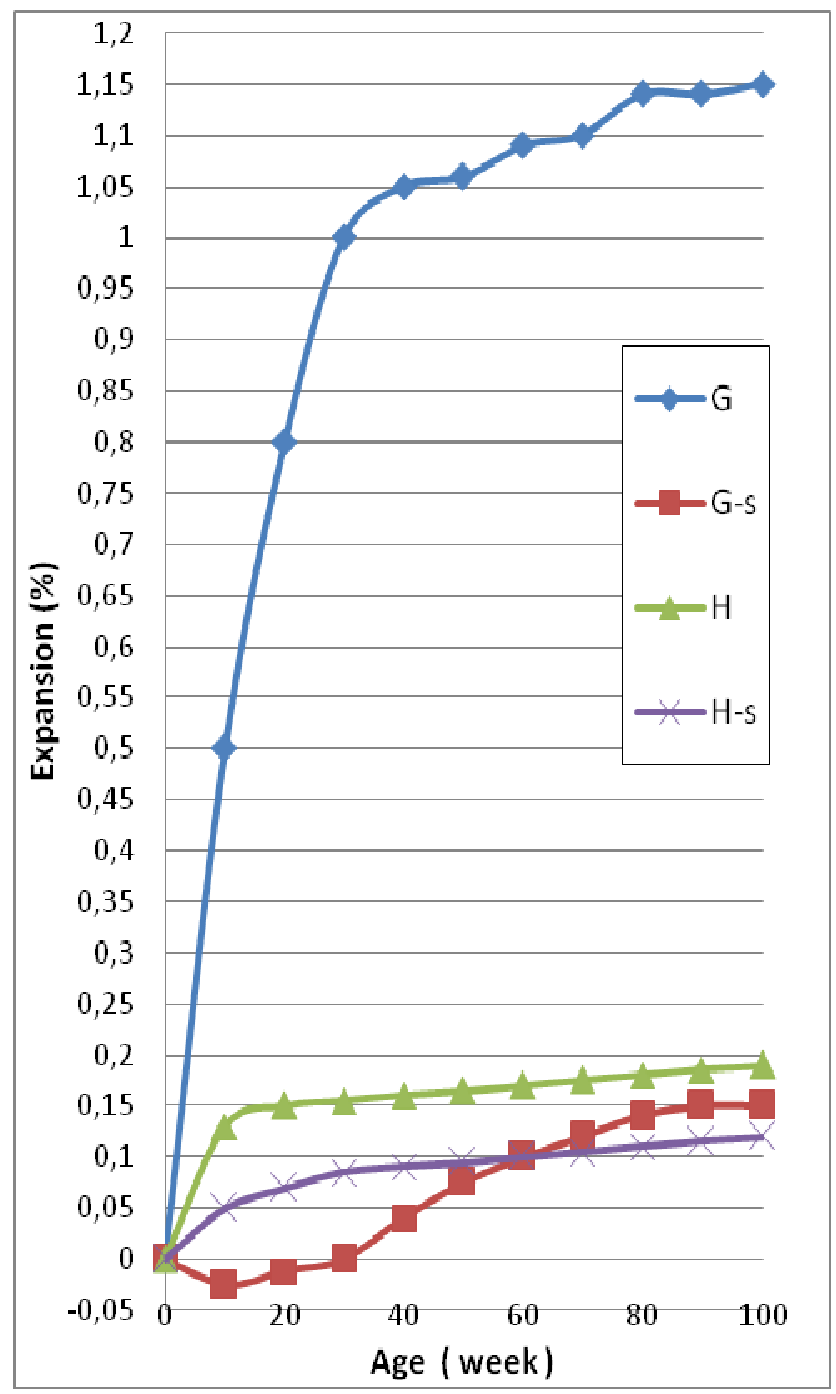

Fig.3. Expansion of concretes versus time, cured at $60^{\circ} \mathrm{C}$ and $100 \% \mathrm{RH}$.
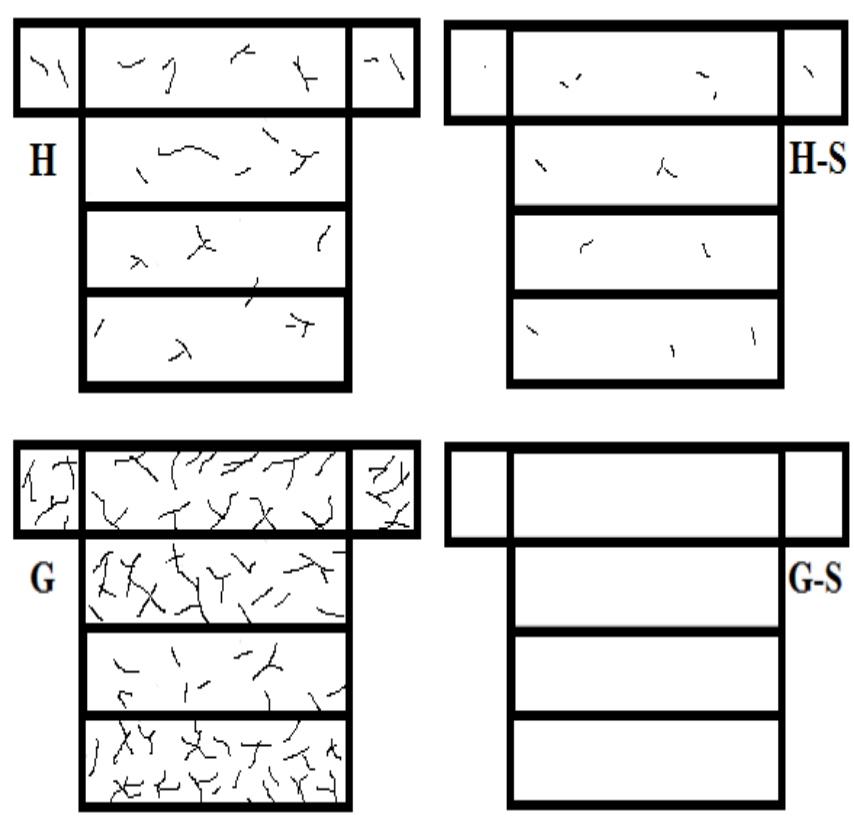

Fig.4 Influence of ground slag on surface cracking of concrete.

At the same age, the compressive strength (fc) of each concrete formulation was measured on three $(10 \mathrm{x} 10 \mathrm{x}$ 10) $\mathrm{cm}^{3}$ cubes. These values are reported in Table 3. The supplementary data fc $=33 \mathrm{MPa}$ relates to a concrete with same proportioning and curing as the $\mathrm{H}$ and $\mathrm{G}$ series but with innocuous aggregates. It can be seen that addition of ground slag enhances the compressive strength of all concretes.

Table. 3 Influence of ground slag on compressive strength of concretes (age 34 weeks)

\begin{tabular}{|l|c|c|c|}
\hline Aggregate & $\mathrm{H}$ & $\mathrm{G}$ & $\mathrm{R}^{\mathrm{a}}$ \\
\hline Without ground slag (MPa) & 31 & 44 & 33 \\
\hline With ground slag (MPa) & 37 & 70 & - \\
\hline Increase in compressive strength (\%) & 16 & 37 & - \\
\hline $\begin{array}{l}\text { a concrete with innocuous aggregate having the same mixture } \\
\text { design and the same curing conditions as other concretes with } \\
\text { reactive aggregates }\end{array}$ \\
\hline
\end{tabular}

Summarizing, as previously described the selected reactive aggregates present a different kinetics of reaction in accordance with their composition. Then, the manifestations of ASR and the damage produced are quite different. An assessment of the beneficial activity of ground slag against ASR deterioration needs to correlate the different components: expansion as defined by its maximum value and maximum speed, surface cracking and compressive strength. Table 4 summarizes the main differences of each concrete. 
Table 4 Influence of ground slag on the properties of concrete (relative to ASR)

\begin{tabular}{|c|c|c|c|c|}
\hline & & & $\mathrm{H}$ & $\mathrm{G}$ \\
\hline Expansion & $\begin{array}{l}\text { Without } \\
\text { slag }\end{array}$ & $\begin{array}{l}\text { Final expansion } \\
(\%)\end{array}$ & 0.20 & 1.07 \\
\hline & & $\begin{array}{l}\text { Maximum } \\
\text { expansion rate } \\
(\mu \mathrm{m} / \mathrm{m} / \text { week })\end{array}$ & 395 & 1025 \\
\hline & $\begin{array}{l}\text { With } \\
\text { slag }\end{array}$ & $\begin{array}{l}\text { Reduction of } \\
\text { expansion }(\%)\end{array}$ & 36 & 96 \\
\hline & & $\begin{array}{l}\text { Reduction of } \\
\text { expansion rate } \\
(\%)\end{array}$ & 63 & 98 \\
\hline & & $\begin{array}{l}\text { Acceptance } \\
\text { criteria P18-454 }\end{array}$ & no & yes \\
\hline Cracking & $\begin{array}{l}\text { Without } \\
\text { slag }\end{array}$ & $\begin{array}{l}\text { Cracking length } \\
\left(\mathrm{cm} / \mathrm{cm}^{2}\right)\end{array}$ & 0.23 & 0.10 \\
\hline & $\begin{array}{l}\text { With } \\
\text { slag }\end{array}$ & Reduction (\%) & 91 & $\approx 100$ \\
\hline $\begin{array}{l}\text { Compressive } \\
\text { strength }\end{array}$ & $\begin{array}{l}\text { Without } \\
\text { slag }\end{array}$ & $\begin{array}{l}\text { Compressive } \\
\text { strength (MPa) }\end{array}$ & 31 & 44 \\
\hline & $\begin{array}{l}\text { With } \\
\text { slag }\end{array}$ & $\begin{array}{l}\text { Increase in } \\
\text { compressive } \\
\text { strength (\%) }\end{array}$ & 16 & 37 \\
\hline
\end{tabular}

\section{Conclusion}

The experiments reported in this paper were intended to verify the following hypothesis: the harmful effects of ASR induced by an alkali-reactive aggregate can be counteracted by the beneficial activity resulting from the addition of a finely ground slag.

The work was carried out on concretes incorporating two alkali-reactive aggregates, with or without slag added. The concretes were cured at $60^{\circ} \mathrm{C}$ and $100 \% \mathrm{RH}$ and their expansion was measured for up to 88 weeks. In these conditions, which are different from actual conditions in the field, the following conclusions can be drawn :

1. The addition of slag to concrete containing reactive aggregate can reduce or suppress ASR expansion.

2. The efficiency of slag depends on its content and fineness : Generally the reduction rate varies in the same direction as the substitution rate, In most cases the reduction rate varies in the same direction as the finesse; the increase of finesse lowers expansion.

3. Surface cracking is strongly reduced or suppressed when slag is used in concretes.

4. Slag act as pozzolanes do and counteract, more or less, the decrease of compressive strength caused by ASR.

Before any attempt to extrapolate from laboratory to field concrete, our findings have to be verified on other aggregates and more attention must be paid to the influence of the amount of slag on it activity.

Of course it would be interesting to compare the efficiency of this method with that of mitigation due to mineral admixtures such as silica fume, fly ash, pozzolanne and metakaolin.

\section{References}

1. Hobbs D.W, Effect of mineral and chemical admixtures on alkali aggregate reaction. $8^{\text {th }}$ ICAAR, Kyoto, Japan, (1989).

2. Peter P. Hudec and Joseph A.Larbi, Chemical treatments and additives to minimize alkali reactivity. $8^{\text {th }}$ ICAAR, Kyoto, Japan, (1989).

3. G.K.Moir and J.S.Lumley, Influence of partial cement replacement by ground granulated slag on the expansion of concrete prisms containing réactive silica. $8^{\text {th }}$ ICAAR, Kyoto, Japan, (1989).

4. R.N.Swamy and M.M. Al-Asali, Effectiveness of mineral admixtures in controlling ASR expansion. $8^{\text {th }}$ ICAAR, Kyoto, Japan, (1989).

5. Hiroshi Nomachi and al, Effects of admixtures on expansion characteristics of concrete containing reactive aggregate. $8^{\text {th }}$ ICAAR, Kyoto, Japan, (1989).

6. Yoshihiko Ohama and al, Inhibiting alkaliaggregate reaction with chemical admixtures. $8^{\text {th }}$ ICAAR, Kyoto, Japan, (1989).

7. Guidelines for alkali-aggregate reactions in concrete. German Building Standars Committee of the Deutsches Institute fur Normunge ev,(1986).

8. Japanese standards Association. ready mix concrete. JSA, Tokyo, (1986).

9. Alkai-silice reaction : minimizing the risk of damage. Guidance notes and model specification clauses. Concrete Society, London, Technical Raport 30,(1987).

10. Kollak J.J and al. Measurement of $\mathrm{OH}^{-}$ion concentrations of pore fluids and expansion due to alkali-silica reaction in composite cement mortars. 8 th ICCC, Rio de Janeiro, (1986).

11. Hobbs D.W, Deletarious expansion of concrete due to alkali-silica reaction : Influence of pfa and slag. Mag -concr -res , (1986).

12. Kawamura M. and al, Effet of various pozzolans additives on alkali-silica expansion in mortars made with two types of opaline reactive aggregates. 38 th annual meeting of Japan Cement Association, Japen, Tokyo, 92-95, (1984).

13. Nishikawa T, Takatsu M, Daimon M (1995) Mechanical properties of mortars containing glass powder. 49th annual meeting of Japan Cement Association 49:114-119

14. Polley C, Cramer SM, de la Cruz RV, Potential for using waste glass in Portland cement concrete. J Mat Civ Eng 10:210-219, (1998)

15. Yixin S, Lefort T, Moras S, Rodrigues D, Waste glass: a possible pozzolanic material for concrete. CANMET/ACI Int Symp on sustainable 
development of cement and concrete, Ottawa, 317326. (1998).

16. Hudec PH, Ghamari C, Ground waste glass as an alkali silica reactivity inhibitor. In: Proceedings of the 11th International Conference on AAR in Concrete, Quebec, Canada, 663-672, (2000).

17. Kojima $\mathrm{T}$, Takagi N, Haruta $\mathrm{K}$, Expanding characteristics of mortar with glass powder produced from waste bottles. In: Proceedings of the $11^{\text {th }}$ International Conference on AAR in concrete, Quebec, Canada, 673-682, (2000).

18. AFNOR NF XP P 18-594, Aggregates -Test methods on reactivity to alkalies, (2004).

19. AFNOR NF P 18-454, Concrete-Reactivity of a concrete formula with regard to the alkali-aggregate reaction - Performance test, (2004). 